\title{
ZASTOSOWANIE MODELOWANIA MATEMATYCZNEGO W PROJEKTOWANIU MODERNIZACJI SYSTEMÓW ZAOPATRZENIA W WODE NA PRZYKŁADZIE SYSTEMU WODOCIĄGOWEGO GMINY ZATOR (cześć II)
}

\begin{abstract}
Artykuł przedstawia praktyczne zastosowanie specjalistycznego oprogramowania inżynierskiego do modelowania matematycznego istniejących systemów wodociągowych. Przeprowadzone analizy numeryczne dotyczą systemu zaopatrzenia w wodę gminy Zator i związane są z powstaniem i dalszą rozbudową na terenie Zatora Strefy Aktywności Gospodarczej Małopolski Zachodniej (SAG). Inwestycja ta znacząco wpłynie na dotychczasowy sposób pracy nie tylko poszczególnych obiektów wodociągowych, ale również całego systemu wodociągowego. Specyfika omawianego zadania polega na zakładanym pojawieniu się systemie nowych odbiorców o dużym zapotrzebowaniu na wodę, skupionych na stosunkowo niewielkim obszarze, oddalonym od głównych przewodów istniejącej sieci wodociągowej. Wstępne bilanse wskazywały, że obecnie funkcjonujące ujęcia wody nie będą w stanie dostarczyć niezbędnej ilości wody, a uruchomienie nowego ujęcia, położonego przeciwlegle do istniejących prawdopodobnie doprowadzi do odwrócenia dotychczasowych kierunków przepływu w większości rurociągów magistralnych. Głównym celem przeprowadzonych analiz numerycznych było znalezienia optymalnego rozwiązania docelowego zapewniającego sprawne funkcjonowanie całego systemu w nowych warunkach eksploatacyjnych zarówno pod względem technicznym jak i ekonomicznym. W tym celu dokonano wielowariantowej analizy sposobu pracy systemu w nowych warunkach eksploatacyjnych oraz określenie niezbędnych parametrów technicznych poszczególnych obiektów i urządzeń dla różnych wielkości dostawy i rozbioru wody z uwzględnieniem przewidywanego poboru wody na terenie rozwijającej się SAG oraz określenie rodzaju i zakresu związanych z tym niezbędnych modernizacji istniejącego układu wodociągowego.
\end{abstract}

Słowa kluczowe: modelowanie sieci wodociągowych, projektowanie sieci wodociągowych, analizy numeryczne, zapotrzebowanie na wodę

\footnotetext{
${ }^{1}$ Robert Wierzbicki, Instytut Inżynierii Środowiska, Państwowa Wyższa Szkoła Wschodnioeuropejska, ul. Żołnierzy I Armii Wojska Polskiego 1E, 37-700 Przemyśl, tel. 16-7355252, e-mail: r.wierzbicki.12@gmail.com.
} 


\section{Obliczenia hydrauliczne}

\subsection{Wprowadzenie}

Komputerowy model systemu zaopatrzenia w wodę gminy Zator zbudowano z wykorzystaniem oprogramowania opracowanego przez firmę DRR Konsulting, umożliwiającego m.in. przeprowadzenie dynamicznej symulacji pracy systemu wodociągowego dla doby o dowolnie wybranej wielkości zapotrzebowania na wodę [7]. Główne założenia i struktura tego programu zostały opracowane w Instytucie Inżynierii i Ochrony Środowiska Politechniki Krakowskiej. Oprogramowanie wykorzystuje silnik obliczeniowy programu EPANET 2.0 [4], opracowany przez amerykańską Agencję Ochrony Środowiska (EPA).

Obliczenia hydrauliczne wykonano dla dobowych cykli pracy sieci wodociągowej odpowiadających dobom o średnim zapotrzebowaniu na wodę, tak aby w możliwie jak najlepszy sposób odwzorować zbliżone do rzeczywistych przyszłe warunki pracy całego systemu. Celem przeprowadzonych obliczeń było zbadanie warunków pracy systemu dla różnych wielkości dostawy i rozbioru wody ze szczególnym uwzględnieniem przewidywanego poboru wody na terenie rozwijającej się SAG oraz określenie rodzaju i zakresu związanych z tym niezbędnych modernizacji istniejącego układu wodociągowego.

Obliczenia przeprowadzono dla następujących wariantów podstawowych:

- Wariant I - określenie maksymalnej wartości poboru wody na terenie SAG niewymagającej wprowadzania istotnych zmian $\mathrm{w}$ istniejącym układzie hydraulicznym zasilanym wyłącznie z ujęcia w Graboszycach;

- Wariant II - określenie maksymalnej wartości poboru wody na terenie SAG przy zasilaniu systemu z ujęć w Graboszycach i Palczowicach bez wprowadzania istotnych zmian w istniejącym układzie hydraulicznym;

- Wariant III - określenie maksymalnej wartości poboru wody na terenie SAG przy zasilaniu systemu $\mathrm{z}$ ujęć $\mathrm{w}$ Graboszycach oraz Palczowicach z wykorzystaniem nowego przewodu DN160 wzdłuż ul. Oświęcimskiej;

- Wariant IV - badanie warunków dostawy wody na teren SAG z wykorzystaniem nowego przewodu DN160 wzdłuż ulic Granicznej i 1. Maja;

- Wariant V - badanie warunków dostawy wody w rejon SAG poprzez wymianę istniejącego rurociągu DN160 na odcinku od Rabusiowic do ul. J. Słowackiego w Zatorze na DN315;

- Wariant VI - analiza warunków dostawy wody w rejon SAG z wykorzystaniem dodatkowego połączenia DN250 od SUW „Rabusiowice” do ul. M. Kopernika w Zatorze.

Poza wymienionymi wyżej wariantami podstawowymi dokonano szeregu dodatkowych obliczeń mających na celu głębszą analizę sposobu pracy poszczególnych obiektów wodociągowych. 


\subsection{Funkcjonowanie systemu wodociągowego $w$ jego obecnym kształcie}

Obliczenia przeprowadzone dla stanu istniejącego wykazały, że specyficzny wpływ na funkcjonowanie całego systemu wodociągowego ma sposób działania zbiornika „Łysa Góra”. Zbiornik ten z uwagi na swoje położenie w stosunku do źródła zasilania, jakim jest SUW „Graboszyce” oraz obszaru zasilania ma charakter zbiornika bocznego. W przypadku tak zlokalizowanych zbiorników ich działanie w zakresie funkcji wyrównawczej, a nie tylko funkcji zbiornika zapasowego (stałe utrzymywanie określonego zapasu wody na wypadek przerwy w dostawie z ujęć) jest możliwe tylko wówczas, gdy ciśnienia na obszarze zasilania zmieniają się w zakresie umożliwiającym jego swobodne opróżnienie do określonej wartości napełnienia minimalnego, a następnie odtworzenie zapasu wody, gdy ciśnienie w sieci jest większe. Jeśli wahania ciśnienia w rurociągu dopływowo-odpływowym w czasie doby są niewielkie, wówczas poziom napełnienia zbiornika zmienia się $\mathrm{w}$ wąskim zakresie, co przekłada się na czas wymiany wody - ulega on znacznemu wydłużeniu i może wpływać na pogorszenie jakości wody np. w wyniku pojawienia się wtórnego skażenia bakteryjnego.

W omawianym przypadku, aby doszło do przynajmniej częściowego opróżnienia zbiornika „Łysa Góra”, pompownia wody czystej w SUW „Graboszyce" musiałaby przerwać pracę na co najmniej kilka godzin, a następnie być w stanie odtworzyć zapas wody w zbiorniku pokrywając jednocześnie bieżący pobór wody na obszarze zasilania. Aby sprostać tym wymaganiom muszą być spełnione dwa podstawowe warunki: 1) ujęcie i zakład uzdatniania muszą posiadać odpowiednio dużą wydajność chwilową lub dysponować niezbędnym zapasem wody zgromadzonym w zbiornikach wody czystej na terenie SUW; 2) pompownia wody czystej musi posiadać odpowiednio dużą wydajność. Jak wykazują obliczenia, w praktyce jest to niemożliwe, gdyż już przy obecnej wielkości zapotrzebowania na wodę zarówno ujęcie, jak i pompownia wody czystej niejednokrotnie pracują na granicy swoich możliwości technicznych.

Jedną z przyczyn wpływających na sposób współpracy pompowni w Graboszycach ze zbiornikiem „Łysa Góra” jest niewielka pojemność zbiornika kontaktowego na terenie SUW $\left(50 \mathrm{~m}^{3}\right)$, która nie pozwala na bardziej elastyczną pracę tego układu.

Kolejnym czynnikiem wpływającym na tryb pracy zbiornika „Łysa Góra” jest sposób jego współpracy ze zbiornikiem „Grodzisko”. Zbiornik ten ze względu na swoje położenie pracuje w sposób zbliżony do zbiornika przepływowego i jak wykazują obliczenia nieco bardziej dynamicznie reaguje na zmiany wielkości rozbiorów i ciśnienia w sieci. Wynika to przede wszystkim z jego usytuowania względem SUW „Graboszyce” oraz obszaru zasilania. W praktyce, aby nie dopuścić do całkowitego opróżnienia tego zbiornika musi on być niemal w sposób ciągły zasilany z przez pompownię w SUW „Graboszyce”. To, z kolei, blokuje odpływ wody ze zbiornika „Łysa Góra”, gdyż ciśnienie w rejonie Graboszyce-Myto przy pracującej pompowni w Graboszycach jest zbyt duże, aby 
zbiornik był w stanie „oddawać” wodę. Stwierdzono również, że w sytuacji przerwy w dostawie wody z SUW „Graboszyce” i zasilania sieci wyłącznie ze zbiorników to, pomimo, że są one posadowione na podobnych rzędnych, poziomy ich napełnienia nie będą obniżać się równomiernie - w krótkim czasie doszłoby do opróżnienia zbiornika „Grodzisko” bez względu na stan napełnienia „Łysej Góry”. W tym konkretnym przypadku zjawisko przepływów między zbiornikami zachodzi w minimalnym stopniu i praktycznie nie ma wpływu na zrównoważenie poziomów ich napełnien.

Dalsze analizy numeryczne wykazały, że obniżenie minimalnej wysokości napełnienia zbiornika „Łysa Góra” poniżej 2,5 m sł.w. może doprowadzić do całkowitego opróżnienia się zbiornika „Grodzisko”, a co za tym idzie, istotnego obniżenia parametrów dostawy wody niemal na całym obszarze zasilania. Ponadto, jeśli nastawa minimalnej wysokości napełnienia zbiornika „Łysa Góra” byłaby niższa od 3,5 m sł.w., wówczas mogłyby wystąpić problemy z odtworzeniem zapasu wody w zbiorniku „Grodzisko”.

Wnioski z tej części obliczeń zdają się potwierdzać słuszność stosowanych obecnie nastaw sterujących pracą pomp wody czystej w SUW „Graboszyce”, które wynoszą odpowiednio $\mathrm{H}_{\min }=3,5 \mathrm{~m}$ sł.w. i $\mathrm{H}_{\max }=3,65 \mathrm{~m}$ sł.w. Praca zbiornika „Łysa Góra” w tak małym zakresie napełnień zakłóca jednak proces prawidłowej wymiany wody. Zazwyczaj zakłada się, że woda po uzdatnienie powinna dotrzeć do odbiorców w czasie nie dłuższym niż jedna doba. $Z$ obliczeń wynika, że w przypadku zbiornika „Łysa Góra” w ciągu doby wymianie ulega nie więcej jak $120 \mathrm{~m}^{3}$, czyli ok. $1 / 5$ jego pojemności.

Pewną poprawę tej sytuacji, polegającą na zwiększeniu stopnia wymiany wody w zbiorniku „Łysa Góra”, przyniosłoby wykonanie dodatkowego połączenia o średnicy DN110 pomiędzy końcówkami istniejącej sieci na granicy sołectwa Rudze i Zatora. Jak wskazują wyniki obliczeń połączenie to umożliwiłoby obniżenie dolnej nastawy uruchamiającej pompy z wartości $3,5 \mathrm{~m}$ sł.w. do poziomu ok. 2,9 m sł.w., a dzięki temu niewielkie zwiększenie stopnia wymiany wody w zbiorniku bez negatywnego wpływu na sposób pracy zbiornika „Grodzisko".

\subsection{Określenie maksymalnej wartości poboru wody na terenie SAG niewymagającej wprowadzania istotnych zmian $w$ istniejącym układzie sieci, zasilanym wyłącznie z ujęcia w Graboszycach}

W obecnych warunkach zasilania systemu i jego wydolności pod względem przesyłowym oraz pełnym wykorzystaniu wydajności ujęcia i SUW „Graboszyce" (max. $1440 \mathrm{~m}^{3} / \mathrm{d}$.), maksymalna wartość poboru wody na terenie SAG nie może przekroczyć $250 \mathrm{~m}^{3} / \mathrm{d}$, bez wystąpienia sytuacji nadmiernego spadku ciśnienia. Dalszy wzrost poboru na terenie SAG wymagałby dostarczenia do systemu większej ilości wody, co z uwagi na wydajność ujęcia w Graboszycach oraz istniejący układ sieci przesyłowej jest praktycznie niemożliwe. 
Należy przy tym zwrócić uwagę, że w okresach wzmożonych rozbiorów wody w godzinach dziennych ciśnienie na terenie SAG może obniżać się do wartości ok. 2,0 barów, a niekiedy nawet nieco mniejszej. W godzinach nocnych wartość ciśnienia ulegałaby stabilizacji i utrzymywała się na poziomie ok. 4,0-5,0 barów. Stosunkowo duża zmienność wartości ciśnienia roboczego na terenie SAG wynika z sumarycznej wielkości poborów, znacznego zróżnicowania ich wartości w godzinach dziennych i nocnych, a także niedostatecznych zdolności transportowych istniejącej sieci.

W przypadku wykonania dodatkowego połączenia, o którym była mowa w punkcie 1.2 sytuacja uległaby istotnej poprawie, gdyż ciśnienie na terenie SAG w żadnej porze doby nie spadałoby poniżej 3,0 barów przy tej samej ilości pobieranej wody $\left(250 \mathrm{~m}^{3} / \mathrm{d}\right)$.

\subsection{Określenie maksymalnej wartości poboru wody na terenie SAG przy zasilaniu systemu z ujęć w Graboszycach oraz Rabusiowicach $\mathrm{z}$ wykorzystaniem istniejącego układu sieci wodociągowej}

Według obliczeń „bezpieczną” ilością wody, jaką można pobrać na terenie SAG jest ok. $600 \mathrm{~m}^{3} / \mathrm{d}$ przy maksymalnym zapotrzebowaniu godzinowym na poziomie ok. $70 \mathrm{~m}^{3} / \mathrm{h}$. Dalszy wzrost ilości pobieranej wody na terenie SAG, a zwłaszcza wysokie wartości chwilowego poboru w godzinach dziennych, mogą skutkować spadkami ciśnienia poniżej 2,0 barów ciśnienia roboczego. Główną przeszkodą nie jest w tym przypadku zbyt mała wydajność ujęć, lecz niewystarczająca przepustowość sieci, przede wszystkim na odcinku od osiedla Marysin do centrum Zatora i dalej w kierunku SAG. Jest to między innymi efektem wzrostu natężenia przepływu w rurociągu DN160 wzdłuż ulic E. Orzeszkowej i Krakowskiej i dalej w kierunku SAG w wyniku sumowania się przepływu wody z ujęcia w Rabusiowicach oraz wody dopływającej ze zbiornika „Grodzisko”.

\subsection{Określenie maksymalnej wartości poboru wody na terenie SAG przy zasilaniu systemu $z$ ujęć w Graboszycach oraz Rabusiowicach z wykorzystaniem nowego przewodu DN160 wzdłuż ul. Oświęcimskiej}

Wykonanie dodatkowego połączenia DN160 wzdłuż ulicy Oświęcimskiej od ul. J. Słowackiego do połączenia z rurociągiem DN160 w rejonie skrzyżowania z ul. 3. Maja (rys. 1.) poprawia sposób rozprowadzenia wody po terenie SAG i pozwala na zwiększenie poboru do poziomu $760 \mathrm{~m}^{3} / \mathrm{d}$ dzięki częściowemu odciążeniu rurociągów po zachodniej stronie centrum Zatora. Nie rozwiązuje jednak problemu zbyt małej przepustowości rurociągu wzdłuż ul. Krakowskiej.

Wielkość dostawy wody z poszczególnych SUW w wyżej opisanych warunkach kształtowałaby się następująco: SUW „Graboszyce” - $1440 \mathrm{~m}^{3} / \mathrm{d}$, SUW „Rabusiowice” $-820 \mathrm{~m}^{3} / \mathrm{d}$. 


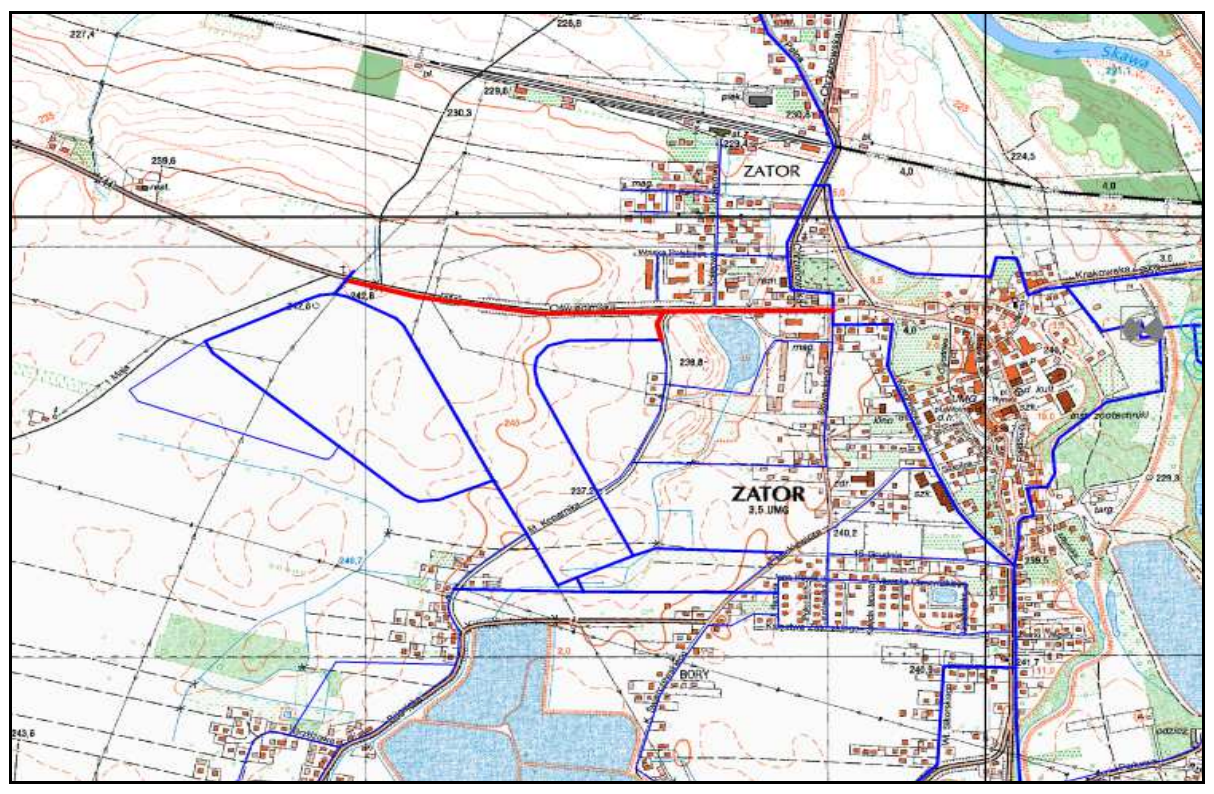

Rys. 1. Lokalizacja proponowanego połączenia DN160 w celu poprawy sposobu dostawy i rozprowadzenia wody po terenie SAG

Fig. 1. The location of suggested link DN160 in order to improve water delivery and distribution in the SAG area

\subsection{Analiza warunków dostawy wody na teren SAG z wykorzystaniem nowego przewodu DN160 wzdłuż ulic Granicznej i 3. Maja}

Jak pokazują wyniki obliczeń, wykonanie dodatkowego połączenia DN160 od końcówki istniejącego przewodu DN160 w rejonie Łowiczek Panieńskich, wzdłuż ul. Granicznej oraz 3. Maja do połączenia z istniejącą siecią na terenie SAG nie będzie miało istotnego wpływu na poprawę warunków dostawy wody do strefy. Wykonanie tego rurociągu zwiększyłoby przepustowość połączeń pomiędzy południową a północną częścią systemu, lecz już w pełni wykorzystana wydajność ujęcia w Graboszycach i tak nie pozwoli na przesłanie większej ilości wody z tego kierunku.

Analiza uzyskanych wyników wskazuje, że główne przepływy z SUW „Graboszyce” w kierunku centrum obszaru zasilania, w tym również SAG koncentrowałyby się na odcinkach: Graboszyce - zb. „Grodzisko” - Palczowice oraz Graboszyce - Rudze - Zator (z wykorzystaniem dodatkowego połączenia DN110). 


\subsection{Analiza warunków dostawy wody w rejon SAG w przypadku wy- miany istniejącego rurociągu DN160 na DN315 na odcinku od Ra- busiowic (miejsce włączenia SUW do sieci miejskiej) do ul. \\ J. Słowackiego w Zatorze}

Pomimo tego, iż analizowane rozwiązanie jest w pełni funkcjonalne i zapewnia dostarczenie wymaganej ilości wody oraz utrzymanie w rejonie SAG ciśnienia nie mniejszego od 2,0 barów w każdych warunkach poboru wody, to wymiana istniejących rurociągów na długości blisko $3700 \mathrm{~m}$ wydaje się być ekonomicznie nieuzasadniona.

Alternatywą dla powyższego rozwiązania jest ułożenie dodatkowego rurociągu o średnicy nie mniejszej niż DN250 (PN10) od projektowanej SUW „Rabusiowice" do zbiegu ulic Oświęcimskiej i M. Kopernika (rys. 2).

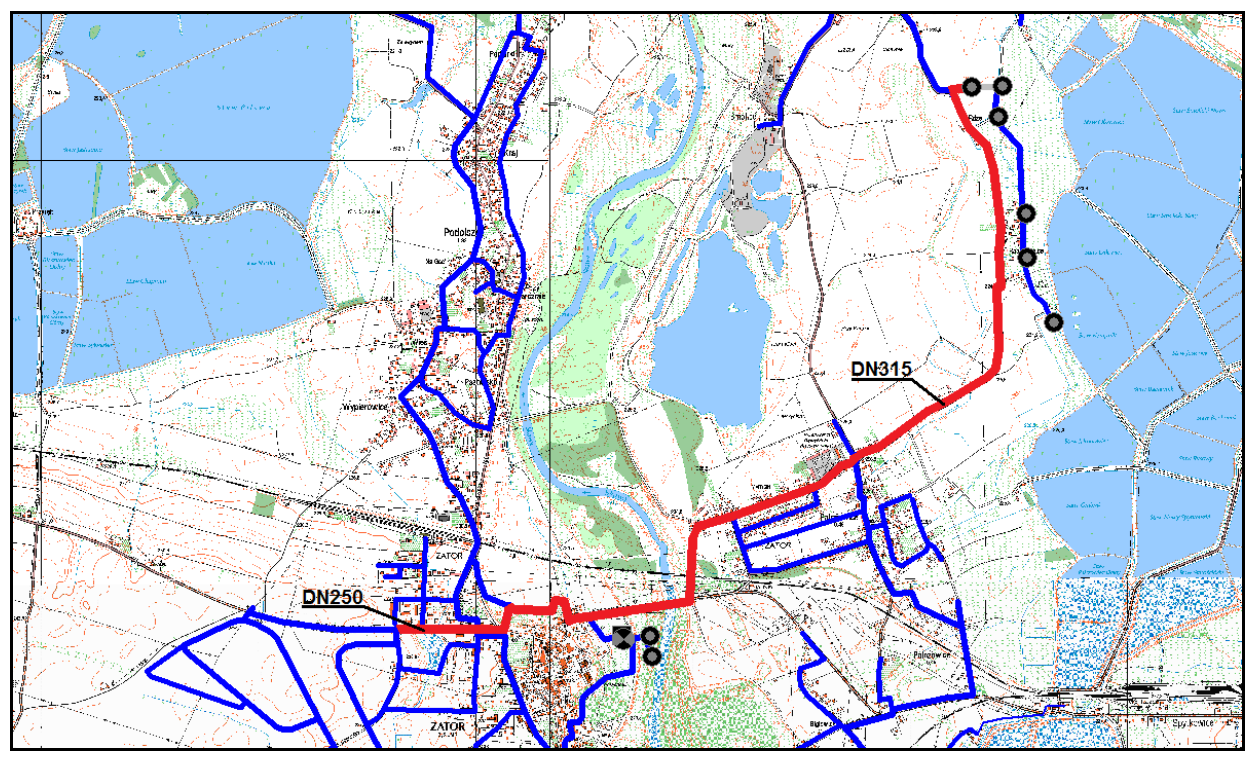

Rys. 2. Zakres ewentualnej wymiany rurociągu DN160 na DN315 na odcinku od planowanej SUW „Rabusiowice” do ul. J. Słowackiego oraz DN250 wzdłuż ul. Oświęcimskiej na odcinku pomiędzy ul. J. Słowackiego i M. Kopernika w Zatorze wraz z proponowanym połączeniem DN160 na odcinku od ul. J. Słowackiego do ul. 3. Maja w celu poprawy warunków dostawy i rozprowadzenia wody po terenie SAG.

Fig. 2. The scope of possible pipeline replacement (DN160 to DN315) on the section from planned water treatment plant "Rabusiowice" to J. Słowackiego street and DN250 in Oświęcimska street between J. Słowackiego and M. Kopernika streets in Zator together with suggested merge DN160 from J. Słowackiego street to 3. May street in order to improve water delivery and distribution in the SAG area 


\subsection{Analiza warunków dostawy wody $w$ rejon SAG z wykorzystaniem dodatkowego połączenia DN250 na odcinku od SUW ,Rabusiowice” do ul. M. Kopernika w Zatorze}

\section{I wariant trasy przewodu}

W wariancie tym woda z SUW „Rabusiowice” byłaby dostarczana do centrum miasta i SAG dwoma rurociągami: istniejącym rurociągiem DN160 Palczowice - Smolice oraz nowym rurociągiem tranzytowym DN250 włączonym do istniejącej sieci w rejonie skrzyżowania ulic Oświęcimskiej i M. Kopernika (rys. 3). Ponadto przewiduje się połączenie nowego przewodu DN250 z istniejącą siecią u zbiegu ulic Chrzanowskiej, Staromiejskiej i Mostowej (DN110) oraz na południe od wiaduktu kolejowego u zbiegu ulic Chrzanowskiej i Wszystkich Świętych (DN160), a także w rejonie skrzyżowania ulic Oświęcimskiej i J. Słowackiego (DN160). Łączna długość tego odcinka wyniesie $4700 \mathrm{~m}$.

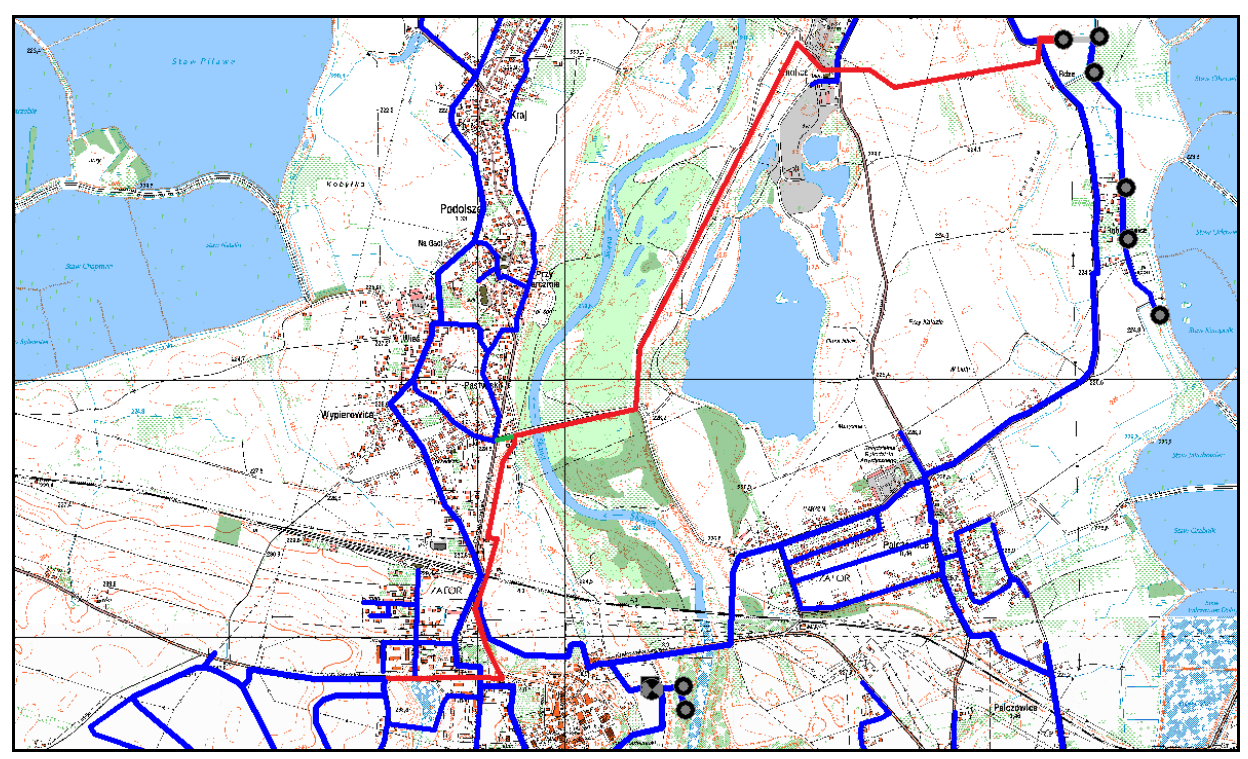

Rys. 3. Schemat I wariantu trasy nowego połączenia DN250 pomiędzy planowaną SUW „Rabusiowice" a węzłem sieci w rejonie ulic Oświęcimskiej i M. Kopernika

Fig. 3. First option scheme of new DN250 connection between planned water treatment plant "Rabusiowice" and network node in the area of Oświęcimska and M. Kopernika streets

Przeprowadzone obliczenia w pełni potwierdzają funkcjonalność tego rozwiązania zarówno pod względem przepustowości połączeń oraz możliwości utrzymania na terenie SAG ciśnień nie mniejszych od 2,2 bara dla wielkości poboru nieprzekraczającego $2155 \mathrm{~m}^{3} / \mathrm{d}$. Istotnym jest, aby nowe połączenie 
o średnicy DN250 zostało doprowadzone do planowanego węzła sieci u zbiegu ulic Oświęcimskiej i M. Kopernika oraz powstał wspomniany wcześniej rurociąg DN160 wzdłuż ul. Oświęcimskiej na odcinku od ul. M. Kopernika do połączenia z siecią na terenie SAG w rejonie ulic Sosnowej i Grabskiego.

Główny ciężar przesyłu wody z ujęć na teren SAG oraz centrum Zatora przejąłby w tym wypadku nowy odcinek tranzytowy DN250, transportując ok. $1820 \mathrm{~m}^{3} / \mathrm{d}$ z maksymalnym natężeniem $38 \mathrm{dm}^{3} / \mathrm{s}$. Istniejącym odcinkiem DN160 Palczowice - Smolice transportowane byłoby ok. $370 \mathrm{~m}^{3} / \mathrm{d}$ z natężeniem do $8 \mathrm{dm}^{3} / \mathrm{s}$. Ujęcie w Graboszycach dostarczałoby ok. $800 \mathrm{~m}^{3} / \mathrm{d}$ przez istniejący przewód DN200 Graboszyce - Rudze oraz ok. $390 \mathrm{~m}^{3} / \mathrm{d}$ z wykorzystaniem połączenia DN160 przez Grodzisko.

\section{II wariant trasy przewodu}

W wariancie tym woda z SUW „Rabusiowice” byłaby dostarczana do centrum miasta i SAG dwoma rurociągami: istniejącym rurociągiem DN160 Palczowice - Smolice oraz nowym rurociągiem tranzytowym DN250 prowadzonym równolegle do istniejącego przewodu DN160 Palczowice - Smolice na odcinku od SUW „Rabusiowice” do Palczowic. W dalszej części rurociąg poprowadzony byłby po północnej stronie zabudowy na terenie Palczowic w kierunku wschodnim do ul. M. Orzeszkowej i wzdłuż niej do ul. Mostowej (rys. 4). Od tego miejsca trasa rurociągu przebiegałaby, tak jak w I wariancie (rys. 3).

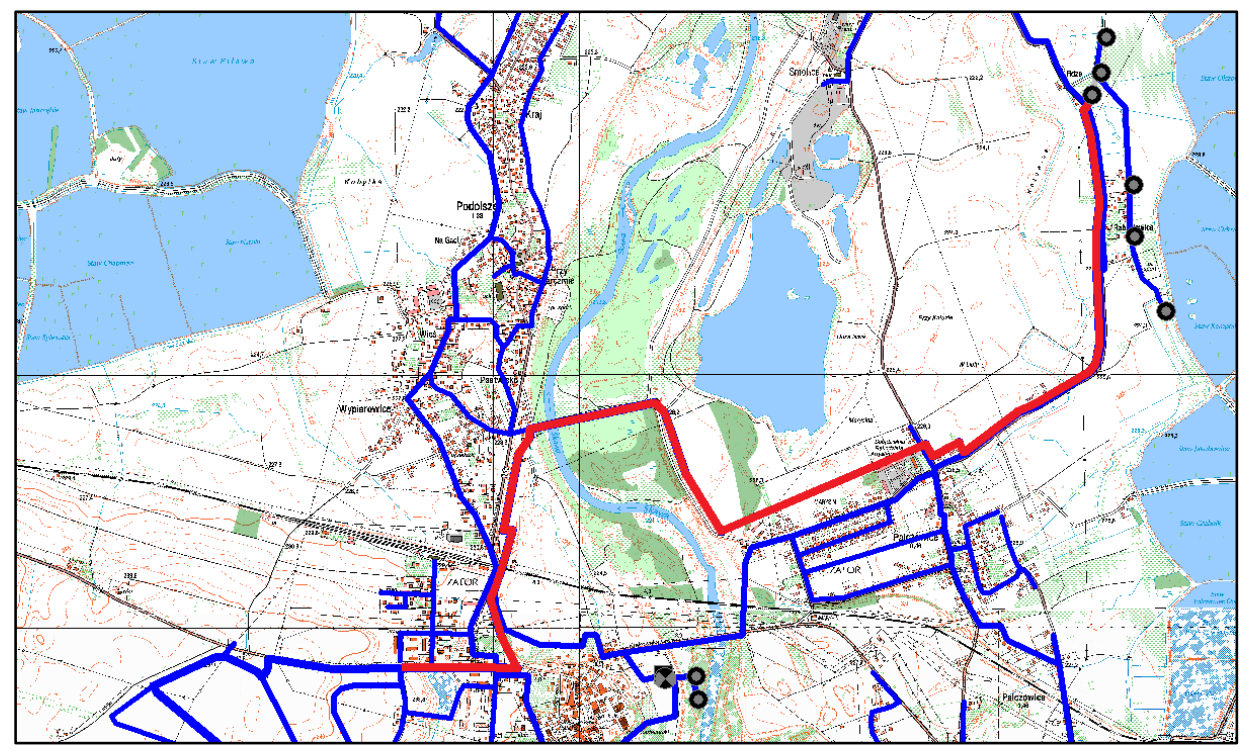

Rys. 4. Schemat II wariantu trasy nowego połączenia DN250 pomiędzy planowaną SUW „Rabusiowice" a węzłem sieci w rejonie ulic Oświęcimskiej i M. Kopernika w Zatorze

Fig. 4. Second option scheme of new DN250 connection between planned water treatment plant "Rabusiowice" and network node in the area of Oświęcimska and M. Kopernika streets in Zator 
W celu poprawy warunków dostawy wody $\mathrm{z}$ ujęcia $\mathrm{w}$ Rabusiowicach w kierunku Trzebieńczyc i Laskowej, zwłaszcza w warunkach awaryjnych, przewiduje się połączenie nowego przewodu DN250 z istniejącym rurociągiem DN160 w Palczowicach w rejonie zbiegu ulic M. Orzeszkowej i Zaskawie. Pozostałe połączenia projektowanego przewodu, opisane w I wariancie - u zbiegu ulic Chrzanowskiej, Staromiejskiej i Mostowej (DN110), na południe od wiaduktu kolejowego u zbiegu ulicy Chrzanowskiej i Wszystkich Świętych (DN160) oraz w rejonie ulic Oświęcimskiej i J. Słowackiego (DN160) - pozostają bez zmian.

W stosunku do I wariantu trasy długość projektowanego połączenia DN250 w II wariancie zwiększy się o ok. 700-750 m i wyniesie łącznie ok. $5400 \mathrm{~m}$. Pod względem hydraulicznym nie wniesie to istotnych zmian w sposobie funkcjonowania całego systemu, a jedynie spowoduje niewielki spadek ciśnienia w godzinach maksymalnego rozbioru wody w jego zachodniej części (rejon SAG). Obliczenia wykazały, że w godzinach maksymalnego poboru, przy uwzględnieniu poboru wody na cele przeciwpożarowe na terenie SAG w ilości $20 \mathrm{dm}^{3} / \mathrm{s}$, ciśnienia robocze $\mathrm{w}$ sieci spadną nie więcej niż o $0,7 \mathrm{~m}$ sł.w, a minimalna wartość ciśnienia na terenie SAG nie powinna spaść poniżej 2,0 barów.

\section{Wnioski}

\subsection{Wybór wariantu modernizacji systemu dystrybucji wody}

Na podstawie analizy wyników przeprowadzonych obliczeń można stwierdzić, że najbardziej korzystnym rozwiązaniem modernizacji systemu wodociągowego gminy Zator jest wariant opisany w punkcie 1.8, którego istotą jest wykonanie dodatkowego połączenia pomiędzy planowaną SUW „Rabusiowice” a strefą SAG w I lub II wariancie jego trasy (rys. 3, 4). Połączenie to powinno posiadać średnicę nie mniejszą niż DN250 i istotne jest, aby zostało podłączone do sieci miejskiej w rejonie skrzyżowania ulic Oświęcimskiej i M. Kopernika, gdyż wcześniejsze włączenie tego przewodu do istniejącej sieci ograniczy jego możliwości przesyłowe i zwiększy wysokość strat hydraulicznych, co negatywnie odbije się na wartości ciśnienia dyspozycyjnego na terenie SAG w godzinach maksymalnego rozbioru wody.

Ważne jest, aby inwestycja ta była powiązana z powstaniem nowego odcinka DN160 wzdłuż ul. Oświęcimskiej od ul. M. Kopernika do połączenia z siecią na terenie SAG u zbiegu ulic Sosnowej i Grabskiego do ul. Oświęcimskiej.

Korzystnym będzie również podłączenie do nowego rurociągu tranzytowego z Rabusiowic istniejącej sieci na terenie Podolsza w okolicach mostu na Skawie, u zbiegu ulic Starowiejskiej i Mostowej oraz na terenie Zatora u zbiegu ulic Chrzanowskiej i Wszystkich Świętych, na południe od wiaduktu kolejowego, a także w rejonie skrzyżowania ulic Oświęcimskiej, J. Słowackiego i T. Kościuszki. 
W ramach planowanej modernizacji sieci powinno również zostać wykonane połączenie DN110 wzdłuż ul. Wadowickiej na odcinku od granicy administracyjnej Zator/Rudze do końcówki istniejącej sieci w okolicach cegielni.

\subsection{SUW „Graboszyce”}

Wyniki obliczeń dla okresu perspektywicznego wskazują, że pomimo uruchomienia ujęcia w Rabusiowicach, podającego wodę do sieci pod ciśnieniem ok. 6,6 bara w ilości $2450 \mathrm{~m}^{3} / \mathrm{d}$, ilość wody, jaka będzie musiała być dostarczanej z ujęcia w Graboszycach [3] nie będzie znacząco mniejsza niż obecnie. Wydajność tego zakładu, w zależności od wartości poboru wody, będzie musiała wynosić ok. 1100-1400 $\mathrm{m}^{3} / \mathrm{d}$ przy maksymalnej wydajności godzinowej sięgającej ok. $60 \mathrm{~m}^{3} / \mathrm{h}$ oraz podobnych do obecnych parametrach ciśnienia wyjściowego. Wynika to przede wszystkim z wzajemnego położenia ujęcia i zbiorników „Łysa Góra” i „Grodzisko” oraz sposobu ich współpracy. Wydajność SUW „Graboszyce” w warunkach poboru z sieci w ilości określonej dla okresu perspektywicznego nie powinna być mniejsza od ok. $1000 \mathrm{~m}^{3} / \mathrm{d}$, gdyż w przeciwnym wypadku może to prowadzić do problemów z utrzymaniem odpowiedniego poziomu napełnień zbiorników, a zwłaszcza zbiornika „Grodzisko”, pomimo zachowania znacznego zapasu wody w zbiorniku „Łysa Góra”.

Zwiększenie obszaru oddziaływania (zasilania) ujęcia w Rabusiowicach, a przez to skutecznego ,podparcia” zbiornika „Grodzisko” od strony północnej, wymagałoby zwiększenia ciśnienia tłoczenia w pompowni wody czystej w SUW „Rabusiowice”, co z kolei spowoduje wzrost ciśnienia do ponad 7,5 bara w północnej, niżej położonej części sieci (Smolice).

Ze względu na istotny wzrost przewidywanego zapotrzebowania na wodę w stosunkowo krótkim horyzoncie czasowym, SUW „Graboszyce” [3] wraz z pompownią wody czystej powinny zostać zmodernizowane i dostosowane do pracy ciągłej z wydajnością do $1100-1400 \mathrm{~m}^{3} / \mathrm{d}$. Zalecane jest również powiększenie pojemności zbiornika kontaktowego na terenie SUW z 50 do minimum $100 \mathrm{~m}^{3}$, co powinno pozwolić na bardziej elastyczną eksploatację całego ciągu technologicznego stacji, pompowni wody czystej oraz samego ujęcia.

\subsection{SUW „Rabusiowice”}

Ze względu na przewidywaną w okresie perspektywicznym wielkość rozbiorów chwilowych, przekładających się na konieczność dostawy wody z ujęcia w Rabusiowicach z wydajnością chwilową dochodzącą do $175 \mathrm{~m}^{3} / \mathrm{h}$, przewyższającej deklarowaną wydajność ujęcia $\left(103 \mathrm{~m}^{3} / \mathrm{h}\right)$, na terenie SUW powinien powstać zbiornik wody czystej o pojemności $200 \mathrm{~m}^{3} \mathrm{z}$ możliwością jego rozbudowy do 385 (400) $\mathrm{m}^{3}$.

Pompownia wody czystej powinna posiadać docelowo zdolność przetłoczenia w godzinach szczytowych do $175 \mathrm{~m}^{3} / \mathrm{h}$, przy ciśnieniu wyjściowym ok. 6,4-6,6 bara, co odpowiada bezwzględnej wysokości ciśnienia tłoczenia 288,0-290,0 m n.p.m. 


\subsection{Zbiornik „Lysa Góra”}

Najważniejsze wnioski z obliczeń dotyczące sposobu funkcjonowania zbiornika „Łysa Góra” w obecnych warunkach opisano szerzej w punkcie 1.2. W okresie perspektywicznym nie należy się spodziewać wystąpienia istotnych zmian w sposobie pracy tego zbiornika. Jego specyficzne położenie w stosunku do ujęcia w Graboszycach powoduje, że nadal będzie on pracował w górnej strefie napełnień z niewielkim stopniem wymiany wody.

Jeśli w przyszłości zaszłaby ewentualna potrzeba zwiększenia pojemności zbiorników sieciowych to należy przede wszystkim rozważać rozbudowę zbiornika „Grodzisko”. Wynika to z jego nieco lepszej lokalizacji w stosunku do położenia ujęć oraz obszaru o największych poborach skupionych.

Należy zwrócić uwagę, że jakiekolwiek wykorzystanie zbiornika „Łysa Góra" jest i będzie możliwe tylko pod warunkiem zasilania go z ujęcia w Graboszycach.

\subsection{Zbiornik „Grodzisko”}

Zbiornik „Grodzisko” pełni istotną rolę w funkcjonowaniu prawobrzeżnej części systemu wodociągowego, natomiast jego oddziaływanie na pozostałą część systemu jest stosunkowo niewielkie. Jego ewentualna rozbudowa i zwiększenie pojemności mogłyby doprowadzić do wzmocnienia funkcji zbiornika wyrównania dobowego pod warunkiem odpowiedniej współpracy z pompownią wody czystej w Graboszycach. Biorąc jednak pod uwagę inne czynniki m.in. istniejący układ sieci w południowej części systemu wodociągowego będzie to trudne do zrealizowania. Zwiększenie pojemności tego zbiornika przede wszystkim zwiększyłoby zapas wody, który mógłby być zużyty w sytuacjach awaryjnych, nie miałoby natomiast negatywnego wpływu na stopień wymiany wody. Ze względu na swoje położenie podstawowym i jedynym źródłem jego zasilania jest i będzie ujęcie w Graboszycach.

\subsection{Zbiorniki wyrównania dobowego na terenie SAG}

Zaleca się, aby przy wydawaniu warunków technicznych dla nowych odbiorców na terenie SAG, których przewidywane zapotrzebowanie na wodę będzie przekraczać $100 \mathrm{~m}^{3} / \mathrm{d}$, obligować ich do budowy lokalnych, terenowych zbiorników wyrównawczych o pojemnościach dostosowanych do właściwej im nierównomierności poboru wody w ciągu doby. Pozwoli to na bardziej stabilną pracę całego systemu zaopatrzenia w wodę, ograniczy wahania ciśnienia w sieci oraz zwiększy niezawodność dostawy. Rozwiązanie to jest istotne dla sposobu oraz kosztów eksploatacji całego systemu, w tym również niezbędnej wydajności, przepustowości czy też kubatury jego składowych. 


\section{Podsumowanie}

Współczesne systemy wodociągowe są skomplikowanymi układami technicznymi składającymi się z szeregu urządzeń i obiektów inżynierskich. Proces ich projektowania na każdym z etapów wymaga uwzględnienia wielu wzajemnie oddziałujących na siebie czynników. Zakres niezbędnych do tego celu informacji oraz ich wzajemne powiązania czynią niekiedy zadanie projektowe niemożliwym do zrealizowania bez zastosowania technik komputerowych opartych na zaawansowanych algorytmach obliczeniowych. Na szczególną uwagę w tym względzie zasługują narzędzia inżynierskie umożliwiające nie tylko analizę sposobu pracy systemu wodociągowego w oparciu o parametry jego funkcjonowania w określonych, statycznych warunkach dostawy i poboru wody, ale przede wszystkim pozwalające na dynamiczną symulację przebiegu zmian wszystkich istotnych wskaźników opisujących system, takich jak np.: natężenia przepływów i ciśnienia w odcinkach sieci, parametry pracy pompowni, bieżący stan napełnienia zbiorników itp.

$\mathrm{W}$ artykule przedstawiono jeden ze sposobów praktycznego zastosowania oprogramowania inżynierskiego wykorzystującego metody modelowania matematycznego dla wypracowania optymalnego wariantu modernizacji istniejącego systemu wodociągowego. W wyniku przeprowadzonych obliczeń ustalono, który $\mathrm{z}$ analizowanych rozwiązań jest optymalnym pod względem funkcjonalnym i ekonomicznym.

\section{Literatura}

[1] Polska Norma: PN-B-02863/Az1 2001. Ochrona przeciwpożarowa budynków. Przeciwpożarowe zaopatrzenie wodne. Sieć wodociągowa przeciwpożarowa.

[2] Polska Norma: PN-EN 1508-2002 - Zaopatrzenie w wodę. Wymagania dotyczące systemów i ich części składowych przeznaczonych do gromadzenia wody.

[3] Projekt budowlany rozbudowy Stacji Uzdatniania Wody „Graboszyce”. Opr.: „EKOTechnika”, mgr inż. B. Zawadzka i mgr inż. S. Zawadzki, 2002.

[4] Rossman L. A.: Epanet 2 User's manual, U.S. Environmental Protection Agency, Cincinnati, OH 45268, EPA/600/R-00/057, September 2000.

[5] Rozporządzenie Ministra Infrastruktury z dnia 14 stycznia 2002 r. w sprawie określenia przeciętnych norm zużycia wody. Dziennik ustaw Nr 8, poz. 70.

[6] Wierzbicki R.: zastosowanie modelowania matematycznego w projektowaniu modernizacji systemów zaopatrzenia w wodę na przykładzie systemu wodociągowego gminy Zator (część I). Czasopismo Inżynierii Lądowej, Środowiska i Architektury Journal of civil engineering, environment and architecture, JCEEA, t. XXXII, z. 62 (3/I/2015), DOI: 10.7862/rb.2015.134, str. 511-522. Rzeszów 2015. 


\section{IMPROVEMENTS DESIGNING OF WATER SUPPLY SYSTEMS ON THE EXAMPLE OF ZATOR MUNICIPALITY WATER SUPPLY SYSTEM}

\section{S u m m a r y}

The article includes practical application of mathematical modeling techniques using specialized engineering software for designing improvements of existing water supply systems on stage of conceptual design. Presented numerical analysis was related to Zator municipality water supply system. The planned modernization of the system is caused by establishing in Zator Western Malopolska Economic Activity Zone (SAG). A significant increase of predicted water demand and resulting need for additional water intakes fundamentally affects water supply network and related facilities. Localization of new water intake will change current water direction and flow. It will also change the way of exploitation of water tanks and required flow rate for pumping stations. The aim of described numerical analysis is to check how the system will work under new conditions as well as to define required technical parameters of particular objects and devices to find optimal functioning of the system in new conditions. Conclusions from this type of analysis is a set of guidelines for the building-executive project.

Keywords: numerical analysis, modeling of water supply systems, water supply, water system designing

Przestano do redakcji: $30.05 .2015 \mathrm{r}$.

Przyjęto do druku: $1.12 .2015 \mathrm{r}$.

DOI: $10.7862 / \mathrm{rb} .2016 .138$ 